\title{
STRATEGI TRANSFORMASI TATA KELOLA PAJAK BUMI DAN BANGUNAN SEBAGAI ROLE MODEL DESENTRALISASI FISKAL (STUDI KASUS DI PEMERINTAH KOTA CIMAHI)
}

\author{
The Transformation Strategy (role model) of Land and Building Tax Decentralitation \\ (Case Study : City of Cimahi Government)
}

\author{
Amin Saefudin ${ }^{1}$, Lukman M Baga ${ }^{2}$, Bambang Juanda ${ }^{3}$ \\ ${ }^{1}$ Administrasi Bidang Pajak Daerah, Dinas Pendapatan Pengelolaan Keuangan dan Aset Daerah (DPPKAD) \\ Kab. Kebumen. Email: iman_dulangmas@yahoo.co.id \\ ${ }^{2}$ Staf Pengajar Departemen Agribisnis, Fakultas Ekonomi dan Manajemen, IPB. Email: lukmanmb@yahoo.com \\ ${ }^{3}$ Staf Pengajar Departemen Ilmu Ekonomi, Fakultas Ekonomi dan Manajemen, IPB. Email: \\ bbjuanda@yahoo.com
}

\begin{abstract}
Land and Building Tax (PBB) was a state tax imposed on the land and or buildings. Under Article 185 of Law Number 28 of 2009 was transferred from central government to local governments. The aim of the research was to find out the transformation strategy (role model) of land and building tax decentralitation ( case study in Cimahi). The Case Approach examined the reasons of the municipality policies and strategies in the public service with a variety of stakeholder perspectives. The result of it suggested that there were four steps in low enforcement related the land and building tax credit. The Statute Approch was an argument to solve the issues faced. It suggested that there were four local regulation must be implemented. Last the principles of Conceptual Approach based on many expert opinions such as scientists, practitioners and policy makers. The results suggested that there were twelve indicators represented the performance of value for money in the course of their activities.Finally The Blue Ocean Strategy (BOS) throught created, deleted, reduced and increasedinto account the vision of regency development Cimahi, 2005 to 2025 were required the new policy programs in fiscal decentralization that was out of the status quo.
\end{abstract}

Keywords: BOS, Case Approach, Conceptual Approach, Land and Building Tax, Statute Appoach, Vision

\begin{abstract}
ABSTRAK
Pajak Bumi dan Bangunan (PBB) adalah pajak negara yang dikenakan pada tanah dan atau bangunan. Berdasarkan Pasal 185 Undang-Undang Nomor 28 Tahun 2009 dialihkan dari pemerintah pusat ke pemerintah daerah. Tujuan dari penelitian ini adalah untuk mengetahui strategi transformasi (role model) desentralisasi pajak bumi dan bangunan (studi kasus di Cimahi). Pendekatan Kasus meneliti alasan kebijakan kota dan strategi dalam pelayanan publik dengan berbagai perspektif pemangku kepentingan. Hasilnya menunjukkan ada empat langkah dalam penyelesaian piutang PBB. Pendekatan regulasi adalah pendekatan peraturan perundangan untuk memecahkan masalah yang dihadapi. Seharusnya empat peraturan daerah harus ditegakan. Prinsip-prinsip Pendekatan Konseptual berdasarkan pendapat para ahli seperti ilmuwan, praktisi dan pembuat kebijakan. Hasilnya menunjukkan bahwa ada dua belas indikator kinerja nilai uang yang mencerminkan indikator kinerja . Akhirnya Strategi Smudera Biru (BOS) melaui langkah (menciptakan, menghapus, mengurangkan dan meningkatkan) dengan mempertimbangkan Visi pembangunan Jangka Panjang (2005-2025)Kota Cimahi, memunculkan kebijakan program baru dalam desentralisasi fiskal yang mampu keluar dari status quo.

Kata Kunci : BOS, Case Approach, Conceptual Approach, Land and Building Tax, Statute Appoach, Vision
\end{abstract}

\section{PENDAHULUAN}

Pajak Bumi dan Bangunan (PBB) secara konseptual dianggap layak menjadi pajak daerah/kota dengan beberapa kriteria. Pertama PBB layak dipungut oleh daerah karena berkarakteristik lokal, obyek pajak tidak berpindah-pindah (immobile), mempunyai korelasi yang kuat antara pembayar pajak (wajib pajak) dengan yang menikmati pajak tersebut (the tax benefit-link and local accountability. Kedua dengan desentralisasi PBB diharapkan mampu meningkatkan Pendapatan asli Daerah (PAD) dengan memperkuat struktur PBB. Ketiga Pengalihan PBB kepada daerah diharapkan akan mendorong pelayanan kepada masyarakat (public service) yang lebih maksimal, serta 
meningkatkan transparansi dan akuntabilitas dalam pengelolaan PBB. Keempat dibeberapa negaratelah mempraktekan PBB termasuk dalam jenis local tax (Kementrian Keuangan 2012).

Kajian Asian Development Bank(ADB) mengindikasikan minimnya pendapatan daerah yang baru dalam porsi sekitar enam persen dari total pendapatan nasional, sehingga memunculkan pertanyaan kesungguhan pemerintah pusat dalam mengimplementasikan kebijakan dan strategy desentralisasi fiskalmenurut Niazi, etall (2010) . Upaya Perbaikan jenis dan struktur pajak daerah, memperbaiki sistem perpajakan dan retribusi daerah maka diterbitkan Undang-Undang Nomor 28 Tahun 2009 tentang Pajak daerah dan Retribusi Daerah yang biasa disebut juga UU PDRD yang disahkan pada tanggal 15 September 2009 dan terhitung efektif mulai 1 Januari 2010. Dalam pasal 182 ayat (1) UU PDRD menyatakan bahwa paling lambat tahun 2014 PBB-P2 telah dialihkan dari pemerintah pusat ke daerah.

Sebagai komitmen pemerintah pusat terhadap otonomi daerah pemerintah juga menerbitkan Undang-Undang Nomor 23 Tahun 2014 sebagai penyempurnaan Undang-Undang Nomor 32 Tahun 2004 tentang Pemerintah Daerah. Kota Cimahi merupakan kota yang luas wilayahnya paling kecil dan terdiri hanya tiga kecamatan, dengan kepadatan penduduk nomor kedua di Jawa Barat. Juga terdapat kawasan militer terbesar secara nasional dengan delapan pusdiklat militer dan sepuluh markas tentara mencapai tiga puluh persen dari luas wilayah Kota Cimahi yang berdampak pada kebijakan pengeloaan PBB di kawasan tersebut. Pendapatan PBB masih sebagai tulang punggung sebagai Pendapatan Asli Daerah (PAD) Pemkot Cimahi.

Kajian ilmiah sebelumnyaAwi (2004) menyimpulkan hanya pajak daerah yang efektifitasnya naik. Penurunan tingkat efisiensi terkait dengan tidak sebandingnya peningkatan biaya pemungutan PAD dalam periode tersebut. Elastisitas PAD terhadap sektor pertanian, bangunan, keuangan, persewaan dan jasa perusahaan angkanya negatif. Hamdani (2007) menyatakan pada umumnya Dispenda belum mempunyai database yang akurat dan terinci tentang subyek dan obyek pajak. Sembiring (2009) menyimpulkan faktor inflasi tidak berpengaruh signifikan dengan Pendapatan Asli Daerah, dan hanya Pendapatan Perkapita dan Belnja Daerah yang berpengaruh nyata. Hasil penelitian menunjukan bahwa pengelolaan keuangan daerah telah mengalami perubahan dari Orde Baru ke Orde Reformasi namun baru taraf aturan, sedang tatanan operasional, pengelolaannya masih belum banyak mengalami perubahan Helmi (2003). Hasil Selama otonomi daerah Pengelolaan keuangan Kabupaten Bengkalis belum di kelola dengan efektif dan alokasi anggaran yang belum berpihak kepada masyarakat (adil) serta belum inovasinya pemerintah daerah dalam mengelolaan keuangan Gusri (2005).

Dalam kajian pembangunan daerah ini Pemerintah Kota Cimahi (case study) bagian dari salah satu kota di Indonesia yang telah melaksanaan proses pengelolaan PBB, peneliti melakukan kajian analisis guna memberikan rekomendasi Strategi Transformasi Tata Kelola Pajak Bumi Dan Bangunan Pemerintah Kota Cimahi Sebagai Role Model Desentralisasi Fiskal, dari beberapa tujuan kajian:

1. Mengkaji tahapan penyelesaian piutang PBB setelah penyerahan (pasca cut off) pengeloaan PBB dari Pemerintah Pusat kepada Pemkot Cimahi.

2. Menganalisis kebijakan penataan Struktur Orgnisasi dan Tata Kerja (SOTK)Dinas Pendapatan Daerah (Dispenda) KotaCimahi dan regulasi dalam pengelolaan PBB Kota Cimahi.

3. Mendalami inikator- indikator Value For Money (VFM) kinerja PBB Kota Cimahi guna pengelolaan transparansi, akuntabilitas keuangan daerah .

\section{TINJAUAN PUSTAKA}

\section{Perencanaan Strategis}

Perencanaan strategis adalah proses sistematik kesepakatan organisasi dan membangun keterlibatan (networking building) di antara stakeholder terutama prioritas yang hakiki bagi misinya dan tanggap terhadap lingkungan operasi dinyatakan Michael (2013). Pemahaman atas kondisi internal maupun eksternal, dari faktor-faktor terdekat (endogen dan bersifat variabel) hingga terjauh (given, tidak bisa dipengaruhi) adalah bagian dari prasarat untuk membuat perencanaan strategis yang baik serta semakin menjadi kebutuhan dalam kondisi lingkungan yang dinamis dan global . Dalam kerangka otonomi daerah, penyelenggaraan pembangunan daerah tidak semata-mata menjadi tanggung jawab pemerintah daerah, tetapi juga peranan stakeholder pembangunan daerah. Bentuk tanggung 
jawab yang dimaksud misalnya dukungan dari warga masyarakat daerah terhadap terselenggaranya pembangunan daerah yang ditunjukan kondisi shareholder secara aktif warga masyarakat daerah menurut (Fredian, 2014).

\section{Grand Design Desentralisasi Fiskal}

Solihatin (2010) menyebutkan sistem desentralisasi adalah penyerahan urusan pemerintahan pusat kepada daerah sehingga menjadi urusan rumah tangga yang bersangkutan. Terdapat kritikal point menurut Bahl (2008), terdapat dua manfaat dan empat kelemahan desentralisasi fiskal. Manfaat desentralsasi fiskal mewujudkan kondisi efisienasi ekonomi yaitu anggaran daerah untuk pelayanan publik bisa lebih mudah disesuaiakan dengan preferensi masyarakat setempat dengan tingkat akuntabilitas dan kemampuan bayar yang tinggi. Dan peluang meningkatnya penerimaan pajak daerah karena pemerintah daerah dapat memungut pajak dengan basis konsumsi dan aset yang tidak bisa ditarik oleh pemerintah pusat. Sebagai kelemahannya diantaranya lemahnya kontrol pemerintah pusat terhadap ekonomi makro, sulitnya menerapkan kebijakan stabilitas ekonomi dan sulitnya menerapkan kebijakan pembangunan ekonomi dan pemerataan.Termasuk besarnya biaya yang harus ditanggung pemerintah daerah daripada pendapatan yang didapat.

Suatu grand design menguraikan detail perumusan visi dan misi. Visi dan misi ini kemudian diterjemahkan ke dalam beberapa tujuan, strategi serta kebijakan yang harus dilakukan, baik dalam jangka panjang maupun pendek. Arah roadmap dalam misi utama pelaksanaan otonomi daerah dalam hal desentralisasi fiskal yaitu meningkatkan kuantitas dan kualitas pelayanan publik serta kesejahteraan masyarakat, menciptakan efisiensi dan efektifitas pengeloaan sumber daya daerah serta mencipatakan pemberdayaan bagi masyarakat untuk berpartisipasi dalam proses pembangunan disimpulkan Rosidin (2010).

\section{Blue Ocean Strategi Desentralisasi Fiskal}

Blue ocean strategy identik suatu strategi yang berkarakter menantang organisasi untuk keluar dari zona samudera merah persaingan berdarah dengan cara menciptakan ruang pasar yang belum ada pesaingnya, menjadikan kompetisipun menjadi tak relevan.Kim dan Mauborgne (2006). Blue Ocean Strategy (Strategi Samudera Biru) Desentralisasi Fiskal langkah extraordinary suatu daerah dalam menerapkan suatu strategi baru yang mampu keluar dari Status Quo, harus menciptakan strategi masa depan yang gemilang, menerapkan dalam mengatasi kompetisi. Hal-hal yang harus dilakukan yaitu hapuskan, kurangi, ciptakan dan tingkatkan dalam bentuk kerangka kerja empat langkah dalam pelaksanaannya.

\section{Transformasi Reinventing Goverment}

Untuk mecapai keberhasilan transformasi perlu perubahan tujuan, struktur organisasi kekuasaan, sistem insentif, pertanggungjawaban dan sistem budaya. Suatu proses pembaharuan dalam penggantian sistem birokratif menjadi bersifat kewirausahaan, sehingga pemerintah harus siap menghadapi tantangan dalam pelayanan masyarakat secara efektif dan efisien baik saat sekarang mapun yang akan datang.Di Indonesia manajemen perubahan sektor publik telah dinyatakan secara tegas dalam Peraturan Presiden No 81 tahun 2010 tentang grand design reformasi birokrasi maupun peraturan (Menteri Pemberdayaan Aparatur Negara) MENPAN dan Reformasi Birokrasi (RB) No 10 tahun 2011 tentang pedoman pelaksanaan program manjemen perubahan. Bagian dari proses perubahan disebut transformasi dengan berbagai penyebab faktor-faktornya.Dalam suatu manajemen perubahan sektor publik dalam mengukur keberhasilan organisasi sektor publikbukanlah pencapaian keuntungan profit semata, namun lebih pada sebuah tingkat kepuasan atau kepercayaan yang diberikan oleh pemangku kepentingan (stake holder).

\section{Preferensi Hukum}

Dalam ilmu hukum dikemukakan beberapa azas yang sifatnya 'preferensi' sebagai minimal tiga pilihan untuk penyelesaian masaalah atau problem solving sebagai legal analysis konflik. Pertama memakai asas lex posterior (lex posterior derogat legi priori) dimana undang-undang yang demikian mengalahkan yang terdahulu. Selanjutnya asas lex specialist (lex specdialis derogat legi generali) yaituundang-undang khusus mengalahkan yang umum. Sedangkan asas lex superior (lex superior derogat legi inferiori) meletakan Undang-undang yang lebih tinggi mengalahkan yang lebih rendah 
Muhjad, Nuswardani (2012). Peraturan Pemerintah (PP) RI Nomor 60 Tahun 2008 tentang Sistem dan Pengawasan disebutkan bahwa "Prinsip Sistem Pengendalian Intern Pemerintah (SPIP) adalah proses yang integral pada indikator kinerja yang dilakukan secara fokus dan komitmen oleh aparatur pemerintah untuk memberikan keyakinan memadai atas tercapainya tujuan organisasi melalui kegiatan yang efektif dan efisien, keandalan laporan keuangan, pengamanan aset negara, dan ketaatan terhadap peraturan perundang-undangan yang diselenggarakan secara komprehensif di lingkungan pemerintah pusat dan daerah menurut Makawimbang (2014).

\section{Prinsip Pajak Daerah}

Prinsip-prinsip umum perpajakan daerah sebagai berikut, prinsip memberikan pendapatan yang cukup dan elastis, artinya dapat mudah naik turun mengikuti naik dan turunnya tingkat pendapatan masyarakat, adil dan merata secara vertikal artinya sesuai dengan tingkat kelompok masyarakat dan secara horizontal artinya berlaku sama bagi setiap kelompok masyarakat sehingga tidak ada yang kebal pajak, administrasi yang fleksibel artinya sederhana, mudah dihitung, memuaskan wajib pajak, secara politis dapat diterima oleh masyarakat sehingga timbul motivasi dan kesadaran pribadi untuk membayar pajak, nondistorsi terhadap perekonomian, implikasi pajak atau pungutan yang hanya menimbulkan pengaruh minimal terhadap perekonomian disebutkan Rosidin (2010)

\section{Pajak Bumi dan Bangunan}

Sebagaimana nomenklatur Undang-Undang Nomor 28 Tahun 2009 Pajak Daerah dan Retribusi Daerah yang dimaksud Pajak Daerah, yang selanjutnya disebut pajak, adalah kontribusi wajib kepada daerah yang terutang oleh orang pribadi atau badan yang bersifat memaksa berdasarkan undang-undang, dengan tidak mendapatkan imbalan secara langsung dan digunakan untuk keperluan daerahbagi sebesar-besarnya kemakmuran rakyat. Sedangkan Pajak Bumi dan Bangunan Perdesaan dan Perkotaan adalah pajak atas bumi dan/atau bangunan yang dimiliki,dikuasai, dan/atau dimanfaatkan oleh orang pribadi atauBadan, kecuali kawasan yang digunakan untuk kegiatanusaha perkebunan, perhutanan, dan pertambangan. Obyek Pajak adalah Bumi dan / atau bangunan yang dimiliki, dikuasai, dan/atau dimanfaatkan oleh orang pribadi atau badan kecuali kawasan yang digunakan untuk kegiatan usaha perkebunan, perhutanan dan pertambangan. Subyek / Wajib Pajak adalah orang pribadi atau badan yang secara nyata mempunyai suatu hak atas Bumi dan / atau memperoleh manfaat atas bumi dan/atau memiliki dan menguasai, dan/atau memperoleh manfaat atas bangunan.

\section{Indikator Kinerja Keuangan Daerah.}

Sebagai upaya perwujudan tata kelola keuangan pemerintah daerah yang baik (good goverment) diantaranya adalah transparansi informasi kepada publik, akuntabititas indikator kinerja anggaran, pelaksanaan Value For Money (VFM) audit keuangan pemerintah daerah. Akuntabilitas merupakan prinsip-prinsip pertanggungjawaban publik yang berarti selama proses perencanaan, penyusunan dan pelaksanaan harus dapat dipertanggungjawabkan kepada masyarakat. Value for money menyangkut ekonomi, efisiensi dan efektifitas.Ekonomi berarti pemilihan dan penggunaansumberdaya dalam jumlah dan kualitas tertentudengan harga murah. Efisiensi dapat menghasilkan output yang maksimal. Efektifitas penggunaan dana harus mencapai target atau tujuan kepentingan public. Indikator Value of Money merupakan bagian ekspresi pelaksanaan good goverment yang mendasarkan ada tiga elemen dasar secara integral yaitu ekonomi, efisiensi, efektifitas menurut Mardiasmo (2002).

\section{Akuntansi Akrual Basis}

Sesuai amanat Undang-Undang Nomor 17 tahun 2003 tentang Keuangan Negara pengelolaan Anggaran Pendapatan dan Belanja baik pusat maupun daerah untuk menggunakan sistem akuntansi berbasil akrual (accrual basis), paling lambat 5 (lima tahun).Dalam penjabarannya sesua Peraturan Pemerintah (PP) Nomor 24 tahun 2005 perihal Standar Akuntansi Pemerintah dengan berbasiskan Kas menuju Akrual (cash toward accrual). Dalam petunjuk penyelenggaraannya berarti belum menerapkan akrual basis secara penuh (full accrual). Selanjutnya dengan ditetapkannya Peraturan Pemerintah Nomor 71 tahun 2010 tentang Standar Akuntansi Pemerintah yang mengamanatkan bahwa paling 
lambat tahun 2015 baik pemerintah pusat maupun daerah telah menerapkan Standar Akuntansi Pemerintah full accrual.

\section{Kerangka Pemikiran Kajian}

Dalam pemikiran kajian pembangunan daerah mempelajari peranan teori dalam praktek dalam administrasi pembangunan di negara sedang berkembang (Dunia Ketiga) perlu memperhatikan aspek perkembangan yang telah terjadi dalam praktek administrasi pembangunan dalam hubungan masyarakat yang bersangkutan di satu pihak, dan Ilmu Administrasi Pembangunan di pihak lain (Wuisman, 2013).

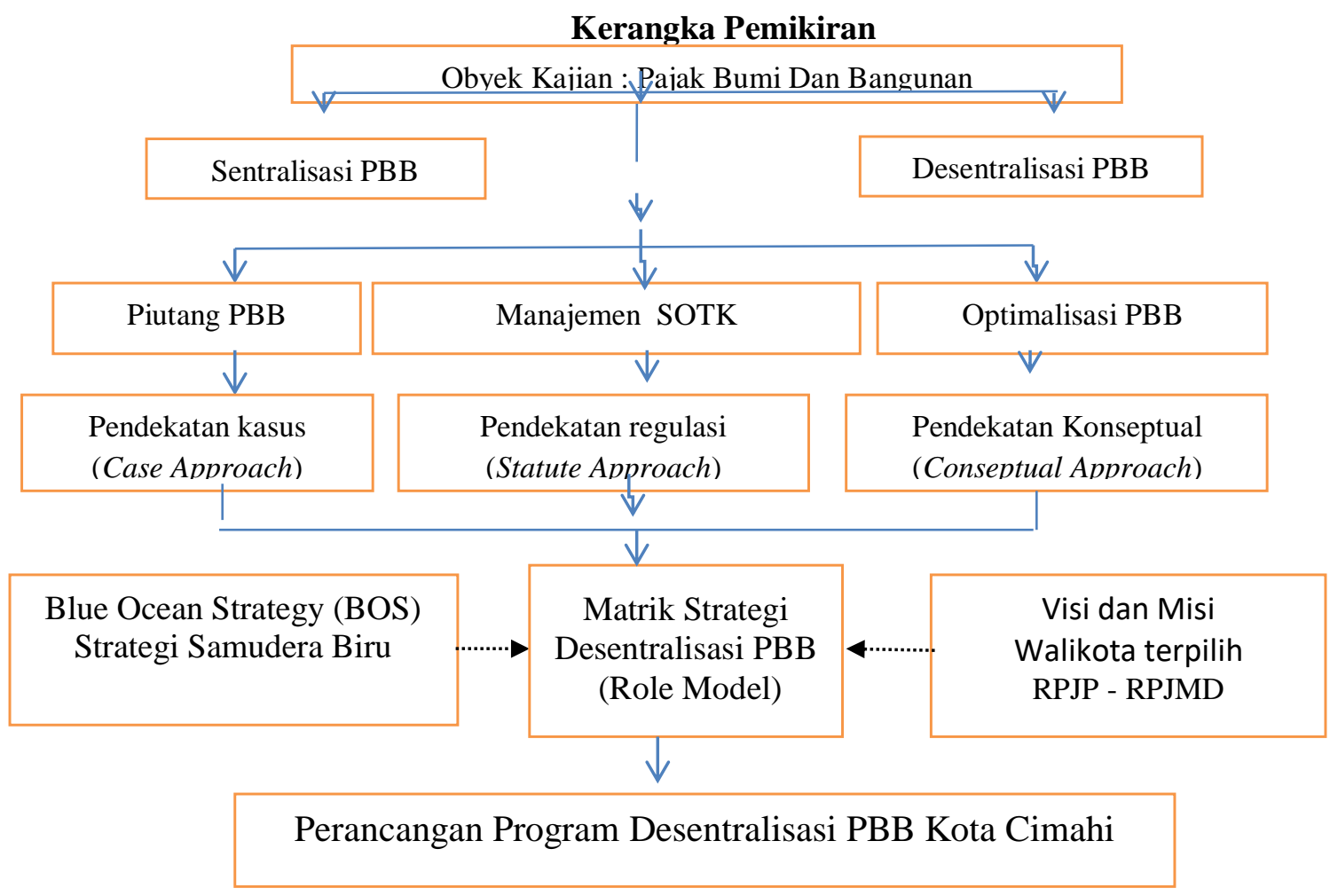

Gambar 1: Kerangka pemikiran Role Model Desentralisasi PBB Cimahi

\section{METODE PENELITIAN}

\section{Metode Pengolahan Data}

Tabel1. Metode Value For Money (VFM)

\begin{tabular}{|c|c|c|c|}
\hline $\mathrm{NO}$ & Metode Pengolahan Data & Rumus Analisis & Keterangan \\
\hline 1 & Elastisitas Kinerja PBB = e $(\%)$ & $e=\frac{\Lambda T R \mathrm{PBB}}{\Lambda Y \mathrm{PAD}} \times \frac{Y P A D}{T P B B}$ & $\begin{array}{l}\mathrm{TR}=\text { penerimaan } \mathrm{PBB} \\
\mathrm{Y}=\text { Pendapatan Asli Daerah }\end{array}$ \\
\hline 2. & $\begin{array}{l}\text { Kontribusi PBB terhadap } \\
\text { APBD=Ks APBD }\end{array}$ & $K s P B B=\frac{\text { RealisasPBB }}{\text { TotalAPBD }} \times 10 \%$ & $\begin{array}{l}\text { Realisasi Pendapatan PBB } \\
\text { Total APBD }\end{array}$ \\
\hline 3. & $\begin{array}{l}\text { Kontribusi PBB terhadap PAD = } \\
\text { KsPAD }\end{array}$ & $K_{S} P B B=\frac{\text { Realisasi } P B B_{i}}{\operatorname{TotalPAD}_{1}} \times 100 \%$ & $\begin{array}{l}\text { RealisasiPendapatan PBB } \\
\text { Total Pendapatan Asli Daerah }\end{array}$ \\
\hline 4. & $\begin{array}{l}\text { Rasio Laju Pertumbuhan PBB = } \\
\text { RPBB }\end{array}$ & $\Delta \mathrm{RPBB}=\frac{\mathrm{PBB}_{1}-\mathrm{PBB}_{(-1-1)}}{\mathrm{PBB}_{(-1-1)}} \times 100 \%$ & $\begin{array}{l}\text { PBBt }=\text { penerimaan PBB tahun- } n \\
\text { PBB }(t-1) \text { Realisasi PBB thn } n-1\end{array}$ \\
\hline 5. & $\begin{array}{l}\text { Derajat Desentralisasi Fiskal } \\
\text { DDF }\end{array}$ & $\mathrm{DDF}=\frac{\mathrm{PAD}_{\mathrm{t}}}{\mathrm{PD}_{\mathrm{t}}} \times 100 \%$ & $\begin{array}{l}\text { PADt : Total PAD Tahun t } \\
\text { TPDt : Total Pendapatan Daerah }\end{array}$ \\
\hline \multicolumn{4}{|c|}{$\mathrm{BB}=\frac{\mathrm{RPBB}}{\pi \mathrm{DP}} \times 10 \%$} \\
\hline
\end{tabular}




\begin{tabular}{|c|c|c|}
\hline 6. & $\begin{array}{l}\text { Rasio Kinerja Pendapatan PBB= } \\
\text { RaK PBB }\end{array}$ & $\begin{array}{l}\text { RaKiPBBt: Realisasi PBB } \\
\text { K PBBt : Ketetapan PBB tahun }\end{array}$ \\
\hline 7. & Efektivitas Pengelolaan PBB & $\begin{array}{l}\text { TPBB }=\text { Ketetapan Pendapatan PBB } \\
\text { PPBB }=\text { Potensi PBB Berjalan }\end{array}$ \\
\hline 8. & Subsidi Rata-Rata Obyek PBB & $\begin{array}{l}\text { SOP = Subsidi Daerah Wajib Pajak } \\
\text { KPBB = Ketetapan PBB }\end{array}$ \\
\hline 9. & Pertumbuhan Anggaran PBB = r & $\begin{array}{l}\mathrm{Pn}=\text { Realisasi Anggaran Tahun } \mathrm{n} \\
\text { Po }=\text { Realisasi Anggaran PBB } \mathrm{n}-1\end{array}$ \\
\hline 10. & Indeks Kemampuan Bayar= IKB & $\begin{array}{l}\text { RPBB }=\text { Realisasi Pendapatan PBB } \\
\text { PPBB }=\text { Potensi Pendapatan PBB }\end{array}$ \\
\hline 11. & Efisiensi Pendapatan PBB = EP & $\begin{array}{l}\text { R PBB }=\text { Realisasi Pendapatan PBB } \\
\text { APBB }=\text { Angaran PBB }\end{array}$ \\
\hline 12. & EfisiensiAnggaran Belanja = EB & $\begin{array}{l}\text { RA PBB = Realisasi BelanjaPBB } \\
\text { APBB = Angaran Belanja PBB }\end{array}$ \\
\hline
\end{tabular}

Selain menggunakan duabelas metode pengolahan datan dalan kajian pembangunan daerah ini dilakukan juga dengan beberapa pendekatan kajian digunakan sebagai berikut seperti dalam bukunya Miner dan Steiner (1997) :

a. Pendekatan kasus (Case Approach), yaitu kajian pendekatan kasus dengan meneliti alasan-alasan kebijakan dan strategi pemerintah yang dipergunakan oleh pemangku kebijakan dalam pelayanan publik dengan berbagai perspektif stakeholder.

b. Pendekatan perundang-undangan (Statute Approach) yaitu pendekatan ini dilakukan dengan menelaah strategi, kebijakan, program desentralisasi fiskal yang dikaji dengan regulasi dan peraturan perundang-undangan yang berlaku.

c. Pendekatan Konseptual (Conseptual Approach), yaitu suatu metode pendekatan melalui pendekatan dengan merujuk pada prinsip-prinsip kajian pembangunan daerah yang diketemukan oleh ilmuwan, praktisi dan pemangku kebijakan.

\section{Lokasi , Waktu dan Data Kajian}

Dilakukan di lingkungan Pemkot Cimahi (Dispenda danBappeda) serta Badan Pusat Statistik (BPS) Kota Cimahi, dari Desember 2015 sampai Oktober 2016. Pengumpulan data data primer (wawancara, observasi, kuisioner) dan data sekunder.

\section{GAMBARAN UMUM}

Secara astronomi Kota Cimahi terletak antara 1070 30'30" - 1070 34' $30^{\prime \prime}$ BT dan 60 50’ 00” - 60 56' 00" LS. Dan secara geografi batas-batas wilayah daerah Kota Cimahi adalah sebagai berikut:

a. Sebelah Utara berbatasan Kecamatan Parongpong, Cisarua, Ngamprah

b. Sebelah Barat : Kecamatan Padalarang dan Batujajar termasuk Kabupaten Bandung Barat.

c. Sebelah Selatan : Kecamatan Margaasih dan Bandung Kulon

d. Sebelah timur: Kecamatan Sukasari, Sukajadi, Cicendo dan Andir di Kota Bandung.

Tahun 1886 dibangun pusat pendidikan militer serta fasilitas lainnya seperti Rumah Sakit Dustira dan rumah tahanan militer.Kota Cimahi dikenal sebagai daerah militer, Kota Cimahi memiliki lahan untuk areal militer yang luas yaitu sekitar 30 persen dari total luas kota. Berbagai jenis pusat pendidikan militer terdapat di Kota Cimahi.Dalam 2014 terdapat lebih dari 15 unit pusat pendidikan militer dan 10 markas tentara juga asrama-asrama.Pada tahun 1935, Cimahi ditetapkan sebagai Kecamatan.Setelah kemerdekaan Indonesia, Cimahi menjadi bagian Kabupaten Bandung Utara. Padatahun1962, dibentuk Kawedanaan Cimahi meliputi Kecamatan Cimahi, Padalarang, Batujajar dan Cipatat. Berdasarkan PP Nomor 29 Tahun 1975, Cimahi ditingkatkan statusnya menjadi kota 
administratif tanggal 29 Januari 1976, dan menjadi kota administratif pertama di Jawa Barat.

\section{Potensi Strategis Kota Cimahi}

Kota Cimahi juga dilintasi oleh jalan nasional yang berfungsi menghubungkan Kota Bandung dan Kota Jakarta, jalan Tollway Cileunyi-Padalarang-Purwakarta, Berdasarkan letak geografis tersebut, Kota Cimahi sangat strategis karena terletak di jalur kegiatan ekonomi regional dan sebagai kota inti Bandung Raya yang berdampingan dengan ibu kota Jawa Barat yang sangat dinamis, memiliki potensi untuk dikembangkan sebagai sentra kegiatan pelayanan jasa yang berbasis pada sumber daya manusia.Di Kota Cimahi peranan perhubungan darat cukup dominan terutama untuk menyalurkan produkproduk industri ke berbagai daerah. Selain itu perhubungan darat sangat dibutuhkan dalam melayani kebutuhan masyarakat terutama dalammenggerakkan roda perekonomian di wilayah kota. Kondisi geohidrologi Kota Cimahi secara umum dibagi kedalam 2 (dua) jenis yaitu air permukaan dan air tanah. Kondisi air permukaan/sungai yang melalui Kota Cimahi yaitu Sungai Cimahi, Sungai Cisangkan, Sungai Cibaligo dan Sungai Cibeureum

Tabel 1.2 Struktur Demografi Penduduk Cimahi Tahun 2014

\begin{tabular}{llllll}
\hline Tahun & Jumlah & Kepadatan & S/R & Laki-Laki & Perempuan \\
\hline 2010 & 541.177 & 13.462 & 102,64 & 274.124 & 267.053 \\
\hline 2011 & 553.592 & 13.770 & 102,32 & 279.966 & 273.626 \\
\hline 2012 & 562.297 & 13.987 & 102.63 & 284.800 & 277.497 \\
\hline 2013 & 570.991 & 14.204 & 101,83 & 288.081 & 282.910 \\
\hline 2014 & 579,016 & 15.300 & 102 & 292.076 & 286.990 \\
\hline
\end{tabular}

Sumber :BPS, Kota Cimahi Dalam Angka 2015

Menurut penggunaannya, lahan di Kota Cimahi tahun 2014 sebesar 36 persen digunakan untuk perumahan. Luas lahan terbesar berikutnya adalah lahan tegalan dan pertanian (sawah/ kolam/ kebun) yaitu sebesar masing-masing 34 persen dan 12 persen.Meskipun relatif luas namun sebagian besar lahan pertanian di Kota Cimahi berada pada daerah perbukitan yang pemanfaatan lahannya belum optimal.Selain itu lahan tersebut sebagian dipertahankan sebagai kantong resapan air.Penggunaan lahan untuk industri sebesar 9 persen dari luas tanah Kota Cimahi.Selama periode 2012 - 2014 terlihat adanya penyempitan wilayah industri, sejalan kontribusinya yang melambat dalam perekonomian Kota Cimahi. Animo penduduk luar untuk bekerja di Kota Cimahi tetap tinggi, implikasinya terjadi peningkatan penggunaan lahan untuk perumahan selama kurun waktu tersebut.

Menurut UU No.9 Tahun 2001 tanggal 21 Juni 2001 Pemerintah Kota Cimahi termasuk ke dalam wilayah Propinsi Jawa Barat dan meliputi 3 Kecamatan yang terdiri dari 15 Kelurahan, yaitu : Kecamatan Cimahi Utara terdiri dari 4 Kelurahan, Kecamatan Cimahi Tengah terdiri dari 6 Kelurahan dan Kecamatan Cimahi Selatan terdiri dari 5 Kelurahan. Sampai saat ini dengan jumlah Rukun Kampung/Warga sebanyak 335 RW dan Rukun Tetangga 1.830 RT. Wilayah Kota Cimahi memiliki luas 40,2 km2. Diantara ketiga kecamatan tersebut Cimahi Selatan merupakan daerah terluas yaitu seluas 16,9 km2dan luasnya terkecil adalah Cimahi Tengah yaitu seluas 10,1 km2 sedangkan Kecamatan Cimahi Utara mempunyai luas 13,3 km2.

Tabel 1.4 Organisasi dan Kewilayahan Kota Cimahi

\begin{tabular}{llllll}
\hline \multirow{2}{*}{ NO } & Nama & Jumlah & Luas & Jumlah & Jumlah \\
\cline { 2 - 6 } & Kecamatan & Kelurahan & Wilayah & RW & RT \\
\hline 1 & Cimahi Utara & 4 & 13,3 & 110 & 571 \\
\hline 2 & $\begin{array}{l}\text { Cimahi } \\
\text { Tengah }\end{array}$ & 6 & 10,1 & 110 & 571 \\
\hline 3 & $\begin{array}{l}\text { Cimahi } \\
\text { Selatan }\end{array}$ & 5 & 16,9 & 115 & 688 \\
\hline & Jumlah & 15 & 40,2 & 335 & 1.830 \\
\hline
\end{tabular}

Sumber BPS :Potensi Kelurahan 2014

Pemerintah Kota Cimahi menjadi kota pertama di Indonesia yang menerapkan integrasi data APBD pada tahun anggaran 2010, hasil Sistem Informasi Pengelolaan Keuangan Daerah (SIPKD) secara elektronik. Program tersebut selaras dengan Kota Cimahi sebagai cyber city, yang bertujuan untuk 
penertiban adiministrasi dan akuntabilitas keuangan daerah. Dengan menjadi pionir dalam integrasi SIPKD elektronik, Kota Cimahi kini menjadi kota percontohan secara nasional.

\section{HASIL DAN PEMBAHASAN}

Pada tanggal 1 Januari 2013 Pemerintah Kota Cimahi telah melaksanakan Desentralisasi Fiskal Pajak Bumi dan Bangunan (PBB ) sesuai amanah Undang-Undang Nomor 28 Tahun 2009 tentang Pajak Daerah dan Retribusi Daerah.Dalam proses transformasi desentralisasi Pajak Bumi dan Bangunan dalam implementasi pengalihan PBB tersebut masih menghadapi berbagai permasalahan. Kondisi demikian mengakibatkan Peraturan Bersama Menteri Keuangan dan Menteri Dalam Negeri yang sudah merevisi ketiga yaitu Nomor 15/PMK.07/2014 dan Nomor 10 Tahun 2014 tentang Tahapan Persiapan Pengalihan PBB menjadi Pajak Daerah.

\section{Piutang PBB}

Tabel 5. Piutang, Ketetapan dan Realisasi PBB Pemkot Cimahi (2013-2016).

\begin{tabular}{cccccc}
\hline Tahun & $\begin{array}{c}\text { Piutang Berjalan } \\
\text { PBB (Cut Off) }\end{array}$ & $\begin{array}{c}\text { PBB Murni } \\
\text { Tahun Berjalan }\end{array}$ & $\begin{array}{c}\text { Potensi Aset } \\
\text { PBB }\end{array}$ & $\begin{array}{c}\text { Target PBB } \\
\text { Dalam APBD }\end{array}$ & $\begin{array}{c}\text { Realisasi } \\
\text { Pendapatan PBB }\end{array}$ \\
\hline B & C & D & E & F & G \\
\hline 2013 & 98.335 .325 .747 & 35.541 .574 .862 & 133.876 .900 .609 & 25.420 .000 .000 & 26.769 .896 .711 \\
2014 & 107.986 .173 .078 & 35.076 .777 .090 & 143.062 .950 .168 & 27.225 .748 .000 & 26.361 .357 .811 \\
2015 & 116.479 .980 .815 & 40.942 .131 .815 & 157.422 .112 .630 & 27.927 .671 .038 & 30.240 .940 .203 \\
2016 & 127.882 .725 .476 & 41.782 .792 .751 & 169.665 .518 .227 & 28.119 .558 .000 & 13.882 .312 .864 \\
\hline
\end{tabular}

Sumber: Pemkot Cimahi

Terjadinya piutang pajak termasuk piutang PBB disebabkan oleh faktor-faktor yang menjadi penghambat dalam kegiatan pemungutan PBBitu sendiriantara lain:

Tabel 6. Faktor-faktor mempengaruhi timbulnya piutang PBB Cimahi

\begin{tabular}{cll}
\hline NO & \multicolumn{1}{c}{ Uraian } & \multicolumn{1}{c}{ Keterangan } \\
\hline 1 & Kurangnya kesadaran/kepatuhan wajib pajak & Tunggakan PiutangPBB Murni \\
2 & Kurang akuratnya penetapan pajak terutang & Database SISMIOP belum update \\
3 & SPPT yang tidak sampai ke wajib pajak & Standar Pelayanan Minimal PBB \\
4 & Kurang optimalnya tindakan PBB & Sumber Daya Aparatur PBB terbatas \\
5 & Permasalahan administrasi pembayaran PBB & Standar Operasional Prosedur PBB \\
6 & Tidak lancarnya eksekusi pengahapusan PBB & Penatausahaan Piutang PBB stagnan \\
\hline
\end{tabular}

Sesuai dengan Peraturan Menteri Keuangan No. 201/PMK.06/2010 tentang Kualitas Piutang Kementerian Negara/Lembaga dan Pembentukan Penyisihan Piutang Tidak TertagihHal ini sangat penting dalam rangka penyajian aset berupa piutang pajak di neraca dengan nilai bersih yang dapat direalisasikan (net realizable value).Menurut Perdirjen Pajak Nomor Per-02/PJ/2013 dan Per07/PJ/2013, kualitas piutang PBB digolongkan dalam 4 (empat) kualitas, yaitu kualitas lancar, kualitas kurang lancar, kualitas diragukan, dan kualitas macet.

\section{Sumber Daya Manusia dan Struktor Organisasi Tata Kerja}

Pemerintah Kota Cimahi telah melakukan Kebijakan Desentralisasi Fiskal PBB tahun 2013, namun Struktur Organisasi dan Tata Kerja masih belum berubah. Dengan adanya kebijakan desentralisasi PBB Kota Cimahi, sebenarnya Pemerintah kota Cimahi dalam hal ini Dinas Pendapatan daerah dapat membentuk Unit Pelaksana Teknis Dinas (UPTD) sesuai ketentuan peraturan perundangundangan dan/atau mengoptimalkan struktur yang ada. 


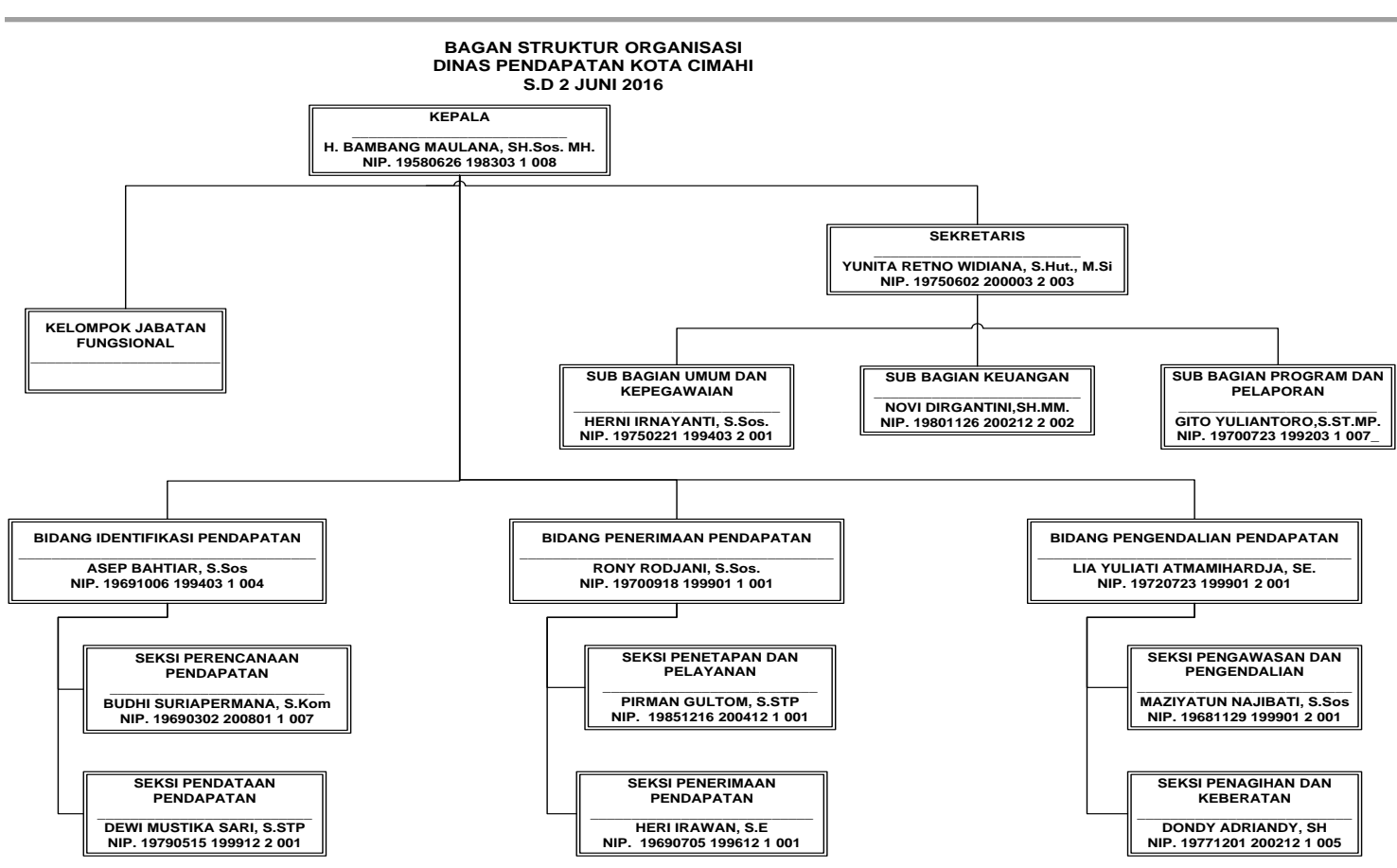

Gambar 2: Struktur Organisasi dan Tata Kerja (SOTK) Dispenda Perda Cimahi No 2 Tahun 2011

Dalam PP No. 41 Tahun 2007 juga disebutkan bahwa susunan organisasi dinas kabupaten/kota paling banyak memiliki 4 bidang dan masing-masing bidang paling banyak terdiri dari 3 seksi. Berdasarkan Permendagri Nomor 56 Tahun 2010 tentang Perubahan Atas Permendagri Nomor 57 Tahun 2007 tentang Petunjuk Teknis Penataan Organisasi Perangkat Daerah, disebutkan bahwa satuan kerja perangkat daerah kabupaten/kota yang menangani fungsi pendapatan, pengelolaan keuangan dan aset daerah ditambahkan fungsinya: penyusunan kebijakan pelaksanaan pemungutan PBB, pendataan, penilaian dan penetapan $\mathrm{PBB}$, pengolahan data dan informasi PBB pelayanan PBB , penagihan $\mathrm{PBB}$, pengawasan dan penyelesaian sengketa pemungutan $\mathrm{PBB}$ dan pelaporan dan pertanggungjawaban pelaksanaan tugas dan fungsi.Dalam pengelolaan PBB kondisi Sumber Daya Manusia sebagai aparatur pendapatan harus siap secara personil dan teknis saat menerima penyerahan kewenangan. Jumlah Pegawai Negeri Sipil (PNS) Dinas Pendapatan Daerah Daerah Kota Cimahi per Oktober tahun 2016 terdiri dari 14 pejabat struktural, 30 staf aparatur PNS dan 26 staf non PNS melengkapi struktur gambar 2 tersebut di atas.

\section{Regulasi Tata Kelola PBB Cimahi}

Tabel 7. Regulasi tata kelola PBB.

\begin{tabular}{llll}
\hline NO & \multicolumn{1}{c}{ Sentralisasi } & \multicolumn{1}{c}{ Undang-Undang } & \multicolumn{1}{c}{ Desentralisasi } \\
\hline 1 & Pajak Daerah dan Retribusi Daerah & Nomor 28 Tahun 2009 & Landasan Desentralisasi PBB \\
\hline 2 & $\begin{array}{l}\text { Rencana Pembangunan Jangka } \\
\text { Panjang Nasional 2005-2025 }\end{array}$ & Nomor 17 Tahun 2007 & $\begin{array}{l}\text { Rencana Pembangunan Jangka } \\
\text { Menengah (RPJMD) }\end{array}$ \\
\hline 3 & Keuangan Negara & Nomor 17 Tahun 2003 & Mankuda Accrual Basic \\
\hline 4 & Perbendaharaan Negara & Nomor 1 Tahun 2004 & Laporan Keuangan Daerah \\
\hline 5 & $\begin{array}{l}\text { Pemeriksaan Pengelolaan dan } \\
\text { Tanggung Jawab Keuangan Negara }\end{array}$ & Nomor 15 Tahun 2004 & $\begin{array}{l}\text { Prinsip Sistem Pengendalian } \\
\text { Intern Pemerintah (SPIP) }\end{array}$ \\
\hline 6 & Penataan Ruang & Nomor 26 Tahun 2008 & Kawasan Strategis Nasional \\
\hline 7 & Pemerintahan Daerah & Nomor 23 Tahun 2014 & SOTK Pemkot Cimahi \\
\hline Sumber :Sekretariat Negara & &
\end{tabular}

Tabel 8. Legal Tarif, NJOP dan NJOPTKP PBB Pemkot Cimahi.

\begin{tabular}{ccccccc}
\hline NO & NJOP & Tarif $\%$ & NJOPTKP & PERWALI & PERDA & Undang-Undang \\
\hline \multirow{2}{*}{1} & NJOP $<50.000 .000$ & 0,15 & & Nomor 24 & Nomor 9 & No. 28 Th 2009 \\
& $50.000 .000<$ & & 10.000 .000 & $\begin{array}{c}\text { Tahun } \\
\text { Tahun }\end{array}$ & Tarif Maksimal
\end{tabular}




\begin{tabular}{ccccccc}
\hline & $1.000 .000 .000<$ NJOP & 0,25 & & & 0,3 persen \\
\hline & NJOP $<1.000 .000 .000$ & 0,11 & & Nomor 12 & Nomor 6 & NJOPTKP \\
& & & 15.000 .000 & $\begin{array}{c}\text { Tahun } \\
\text { Tahun }\end{array}$ & 2013 & 10.000 .000 \\
\hline
\end{tabular}

Sumber: Pemkot Cimahi

\section{Optimalisasi Manajemen Keuangan Pajak Bumi dan Bangunan}

Keberhasilan otonomi daerah akan tercapai jika lembaga sektor publik dikelola dengan memperhatikan Value for Money (VFM).VFM merupakan jembatan untuk menghantarkan pemerintah daerah mencapai good governance, yaituPemerintah

Daerahyang transfaran, ekonomis, efisien, efektif, responsif, dan akuntabel. Tabel 12. Kinerja Pendapatan PBB Pemkot Cimahi (2013 - 2016)

\begin{tabular}{rcccr}
\hline NO & Tahun & Realisasi PBB & Realisasi PAD & \multicolumn{1}{c}{ Realisasi APBD } \\
\hline A & B & C & D & E \\
\hline 1 & 2013 & 26.769 .896 .711 & 191.599 .456 .904 & 975.350 .197 .043 \\
2 & 2014 & 26.361 .357 .811 & 227.949 .120 .180 & 1.117 .121 .948 .297 \\
3 & 2015 & 30.240 .940 .203 & 268.800 .463 .330 & 1.186 .788 .520 .666 \\
4 & 2016 & 13.882 .312 .864 & 172.316 .254 .370 & 815.509 .085 .304 \\
\hline
\end{tabular}

Sumber Dispenda Cimahi

\section{Elastisitas PBB}

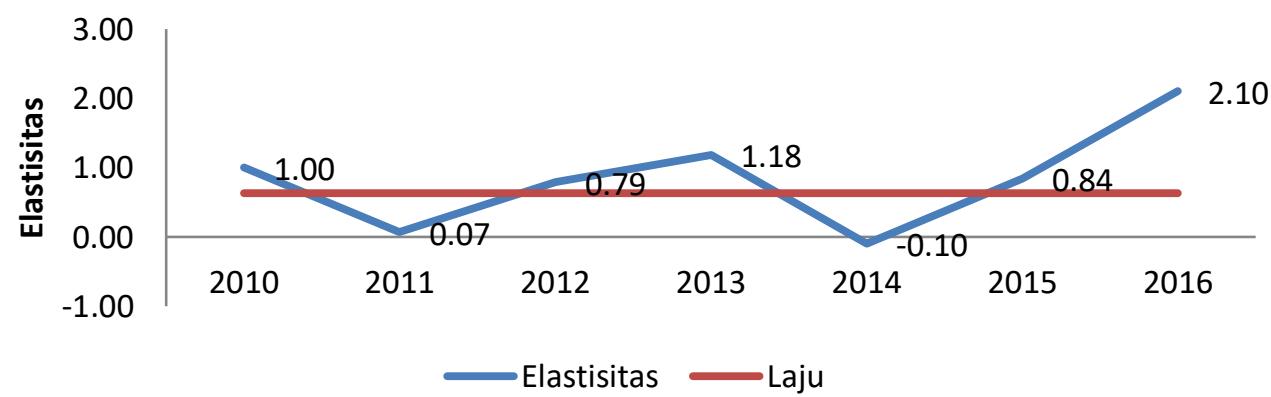

Sumber: Dispenda Kota Cimahi

Gambar 3. Elastisitas Kinerja PBB (2010- Agustus 2016)

\section{Rasio Kontribusi Kinerja PBB terhadap APBD}

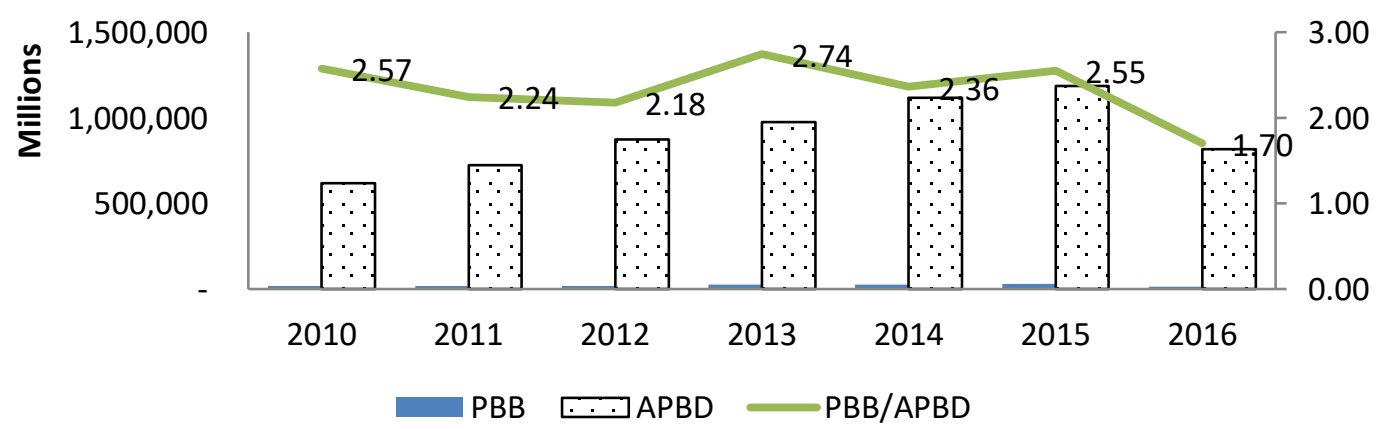

Sumber Dispenda Cimahi

Gambar 4. Kontribusi Pendapatan PBB terhadap APBD Cimahi 


\section{Rasio Kontribusi Kinerja PBB terhadap PAD}

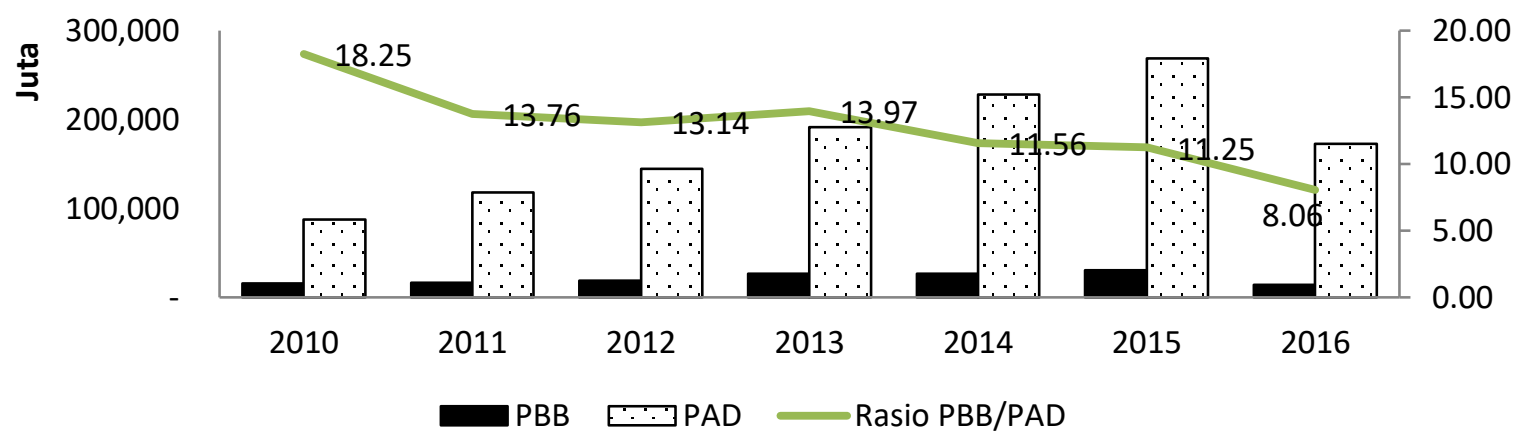

Sumber Dispenda Cimahi

\section{Rasio Laju Pertumbuhan PBB Cimahi}

Gambar 5. Kontribusi Pendapatan PBB terhadap PAD Cimahi

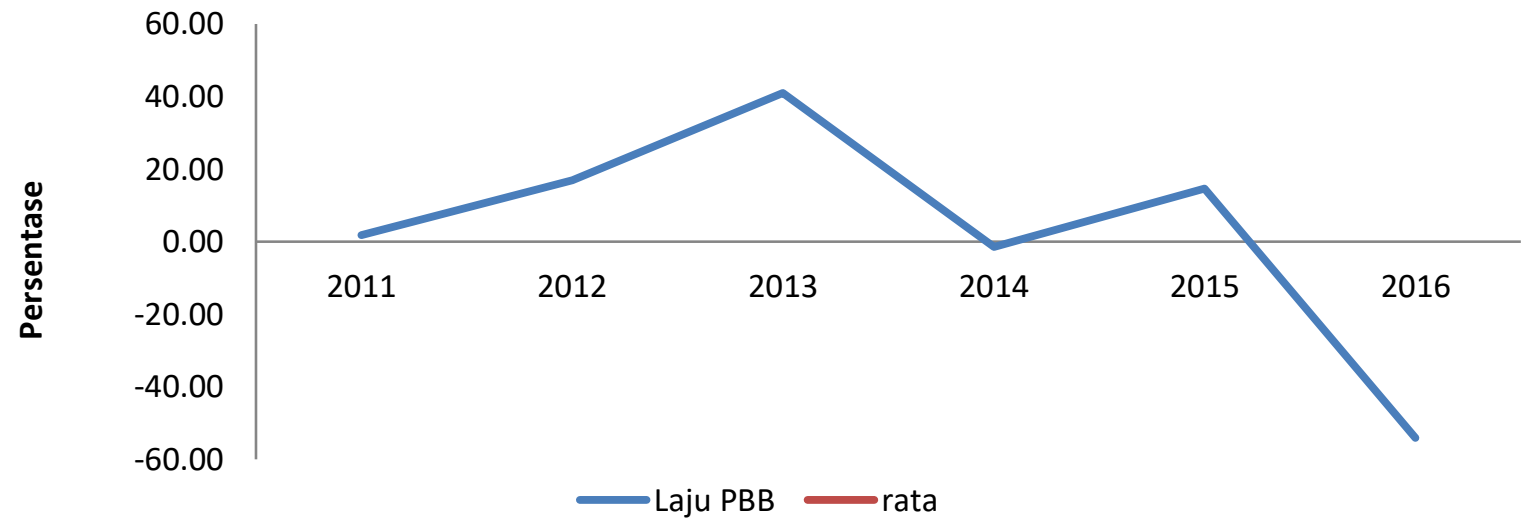

Sumber: Dispenda Kota Cimahi

Gambar 6 Laju Kinerja PBB Pemkot Cimahi

\section{Rasio Derajat Desentralisasi Fiskal}

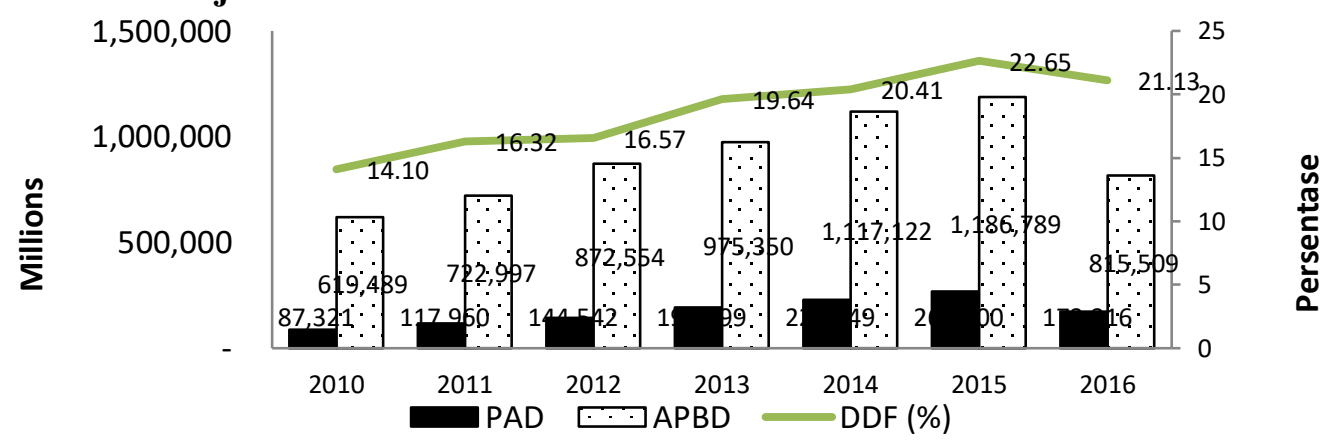

Sumber Dispenda Cimahi

Gambar 7. Derajat Desentralisasi Fiskal Kota Cimahi (2010-2016)

\section{Rasio Kinerja Pendapatan PBB}




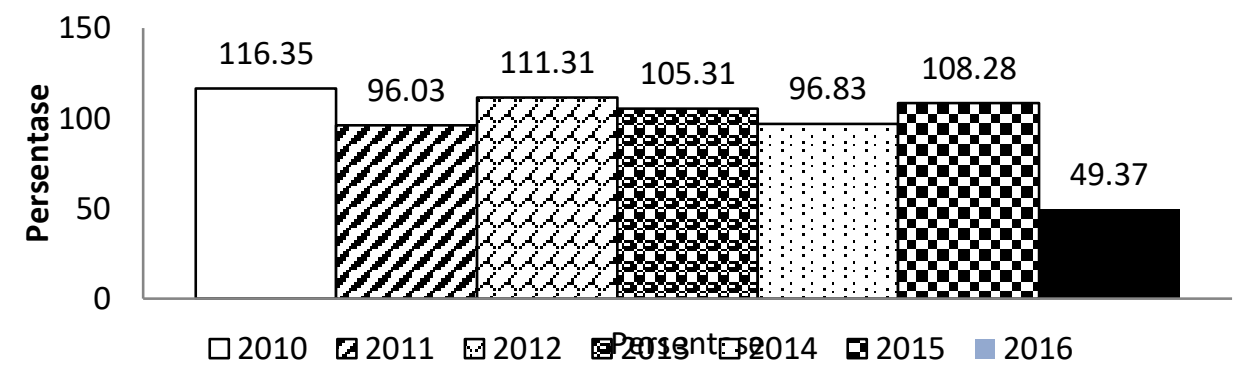

Sumber : Kota Dispenda Cimahi Dalam Angka 2015

6. Efektivitas Pengelolaan PBB

Gambar 8 : Realisasi Kinerja Pendapatan PBB Kota Cimahi

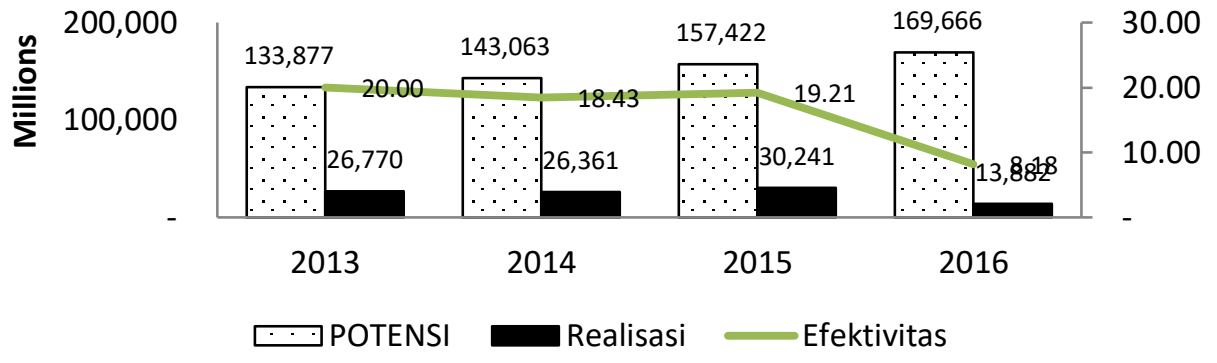

Sumber: Dispenda Kota Cimahi

Gambar9 Efektivitas Kinerja Pendapatan PBB Kota Cimahi

7. Rasio Subsidi Obyek Pajak

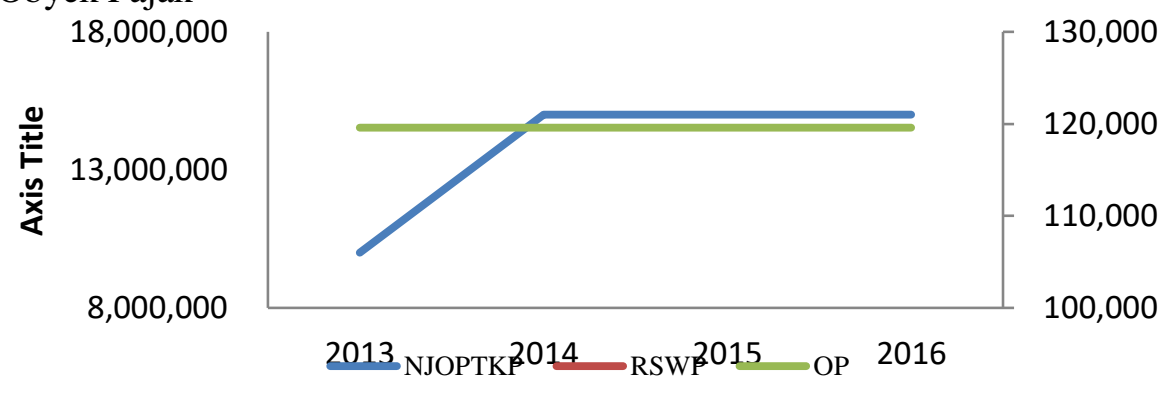

Sumber : Kota Dispenda Cimahi Dalam Angka 2015

Gambar10. Trend Rata-Rata Subsidi Obyek PBB Kota Cimahi

8. Pertumbuhan Anggaran PBB

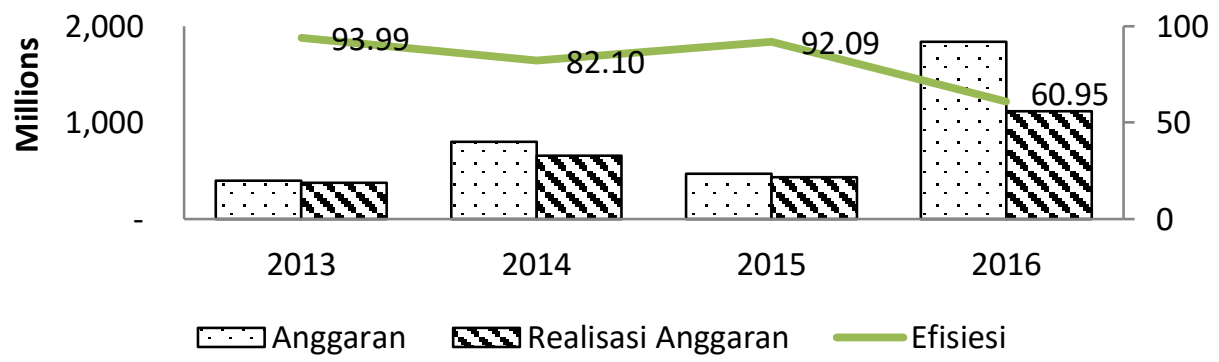

Sumber Dispenda Cimahi

Gambar 11. Trend Rata-Rata Subsidi Obyek PBB Kota Cimahi

\subsection{Indeks Kemampuan Bayar}

Amin Saefundin, Lukman M Baga, dan Bambang Juanda
Strategi Transformasi Tata Kelola Pajak Bumi dan Bangunan Sebagai Role Model Desentralisasi Fiskal (Studi Kasus: Pemerintah Kota Cimahi) 


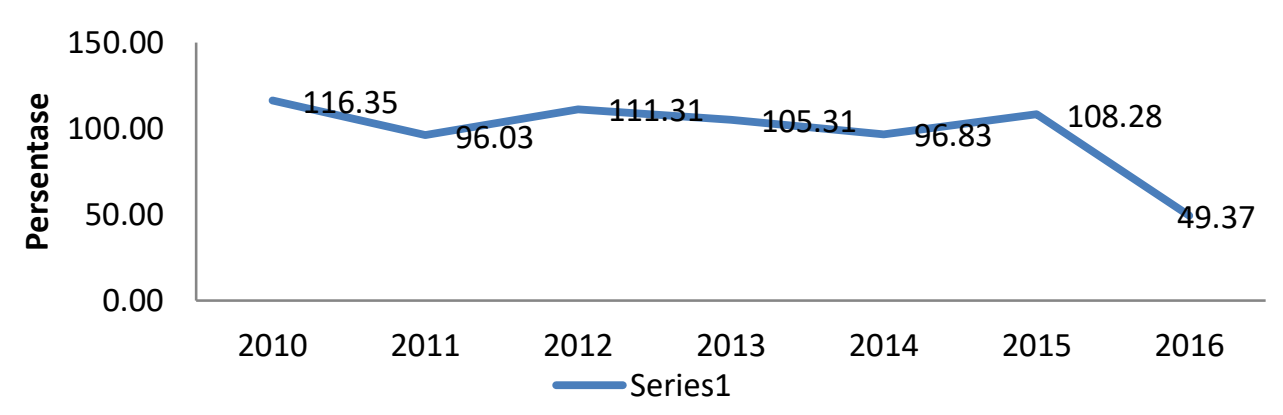

Sumber Dispenda Cimahi

Gambar 12. Indeks Kemampuan Bayar Kinerja PBB (2010- Agustus 2016)

10.Efisiensi Pendapatan PBB

\section{Aesi PBB}

$\begin{array}{llllll} & & & & & \\ & 2.32 & & & & \\ & 2.42 & & 1.61 & \\ 2012 & 2013 & 2014 & 2015 & 2016 \\ & & & & & \end{array}$

Sumber Dispenda Cimahi

Gambar 13. Rasio Efisiensi Kinerja Pendapatan PBB Cimahi

11.Efisiensi Anggaran Belanja PBB

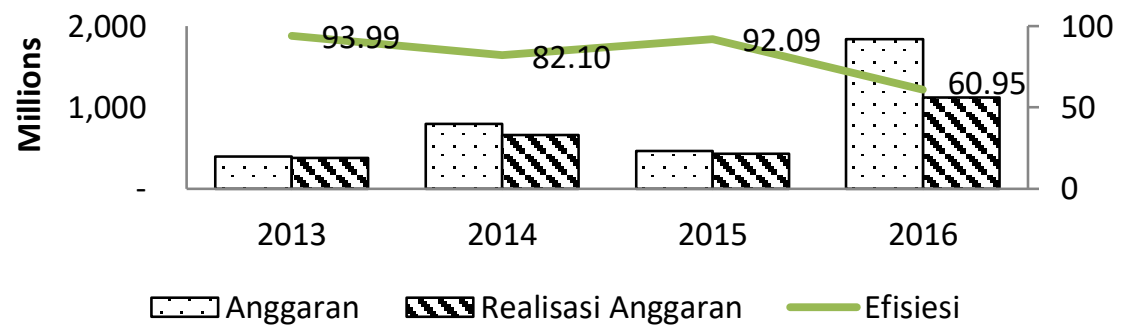

Sumber Dispenda Cimahi

Gambar 14. Efisiensi Penganggaran PBB Pemkot Cimahi

Tabel 15. Rasio Value For Money dan Akuntabilitas Kinerja PBB Kota Cimahi (2010 - 2016)

\begin{tabular}{rlccc}
\hline NO & \multicolumn{1}{c}{ Uraian } & Sentralisasi & Desentralisasi & Rata-rata \\
1 & Elastisitas Kinerja PBB = e (\%) & 0.62 & 0.64 & 0.63 \\
2 & Kontribusi PBB terhadap APBD=Ks APBD & 2.33 & 2.55 & 2.44 \\
3 & Kontribusi PBB terhadap PAD = KsPAD & 15.05 & 12.26 & 13.65 \\
4 & Rasio Laju Pertumbuhan PBB = RPBB & 9.43 & 18.06 & 14.60 \\
5 & Rasio Derajat Desentralisasi Fiskal = DDF & 15.66 & 20.90 & 18.28 \\
6 & Rasio Kinerja Pendapatan PBB= RaK PBB & 107.90 & 103.47 & 105.69 \\
\hline
\end{tabular}

Sumber Dispenda Cimahi

Tabel16. Portofolio Rasio PBB Kota Cimahi (2010-2015)

\begin{tabular}{lll}
\hline No & Uraian & Indikator \\
\hline 1 & Efektivitas Pengelolaan PBB & 16.45
\end{tabular}




\begin{tabular}{cll}
2 & Rasio Subsidi Obyek Pajak = RSOP & 4,084 \\
3 & Pertumbuhan Anggaran PBB = r $(\%)$ & 86.91 \\
4 & Indeks Kemampuan Bayar =IKB & 16.45 \\
5 & Efisiensi Pendapatan PBB = EP & 2.81 \\
6 & Efisiensi Anggaran Belanja PBB = EB & 82.28 \\
\hline Sumber Dispenda Cimahi
\end{tabular}

\section{Perumusan Strategi}

Blue ocean strategy identik suatu strategi yang berkarakter menantang organisasi untuk keluar dari zona samudera merah persaingan berdarah dengan cara menciptakan ruang pasar yang belum ada pesaingnya, menjadikan kompetisipun menjadi tak relevan. (Kim dan Mauborgne 2006). Blue Ocean Strategy (Strategi Samudera Biru) Desentralisasi Fiskal langkah extraordinary suatu daerah dalam menerapkan suatu strategi baru yang mampu keluar dari Status Quo, harus menciptakan strategi masa depan yang gemilang, menerapkan dalam mengatasi kompetisi. Hal-hal yang harus dilakukan yaitu hapuskan, kurangi, ciptakan dan tingkatkan dalam bentuk kerangka kerja empat langkah dalam pelaksanaannya.

Matriks: Tujuan Kajian, Blue Ocean Strategy serta Visi dan Misi Kota Cimahi

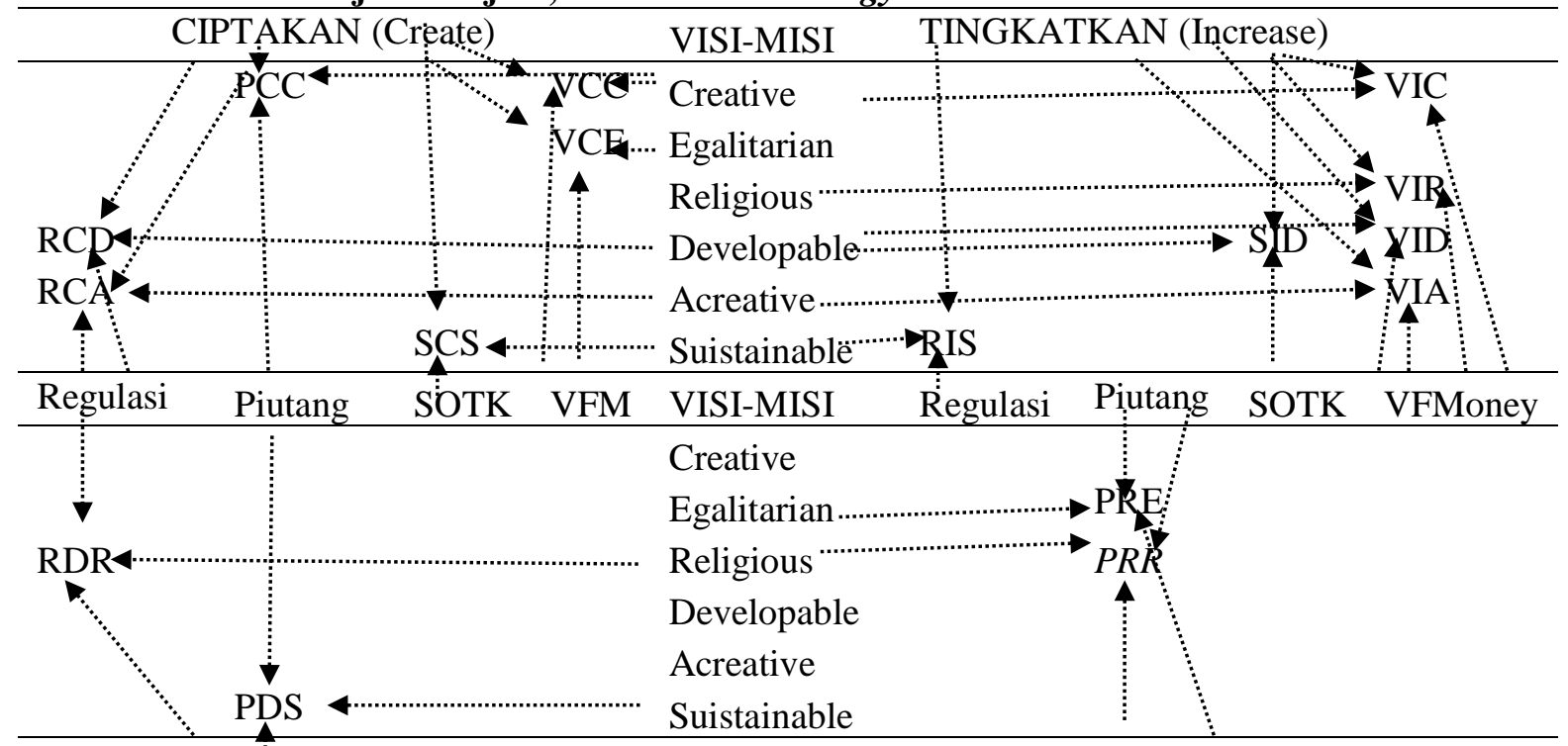

HAPUSSKAN (Delete)

\begin{tabular}{lllll}
\hline NO & Visi dan Misi Kota Cimahi & Tujuan Kajian & Blue Ocean Strategy & Keterangan: \\
\hline 1. & Creative (C) & Regulasi (R) & Ciptakan (Create) & Alur Strategi \\
2. & Egaliter (E) & Piutang (P) & Hapuskan (Delete) \\
3. & Religious (R) & SOTK (S) & Kurangkan (Reduce) \\
4. & Developable (D) & Value For Money (V) & Tingkatkan (Increase) \\
5. & Acreative (A) & & & \\
6. & Suistainable (S) & & & \\
\hline
\end{tabular}

Gambar 15. Matriks Tujuan, Blue Ocean Strategy Desentralisasi PBB dan Visi - Misi Cimahi

Visi dari Kota Cimahi dalam Rencana Pembangunan Jangka Panjang (RPJP) 2005-2025) adalah CIMAHI KOTA "CERDAS", merupakan akronim dari Creatif, Egaliter, Responsif, Dinamis, Agamis dan Berkesinambungan. Kota yang mampu mengatasi rintangan dan ancaman yang timbul serta dapat menjadi kota yang unggul, pengembangan kreativitas dalam produksi, egaliter dalam kehidupan yang demokratis, serta didukung masyarakat yang religius akan berdaya saing untuk membangun kota yang terus maju dan berkembang menuju kemandirian pelayanan kota bagi kesinambungan kehidupan yang lebih baik. Guna mencapai visi Kota Cimahi RPJPD dijabarkan rumusan visi dan misi Pasangan Walikota dan Wakil Walikota terpilih Kota Cimahi tertuang dalam 
Rencana Pembangunan Jangka Menengah lima tahunan (RPJM).

Setelah mengembangkan samudera biru, suatu organisasi dalam hal ini Pemerintah Kota

Cimahi harus melaksanakan startegi yang telah direncanakan tersebut.

1. Strategi samudrera biru melambangkan langkah signifikan dalam meninggalkan status quo.

2. Rintangan kedua yang harus diatasi adalah keterbatasan sumber daya, semakin besar pergeseran dalam strategi yang akan dilakukan, maka akan semakin besar sumber daya yang dibutuhkan dalam mengeksekusi strategi ini.

3. Rintangan ketiga adalah motivasi. Bagaimana memotivasi pelaku stakeholder yang merupakan pemain-pemain kunci untuk bergerak cepat dan tangkas meninggalkan status quo yang telah terjadi selama ini yang menyebabkan belum optimum, efisien dan efektif.

4. Rintangan terakhir adalah rintangan politis, tantangan-tantangan kepentingan dan aturan-aturan (regulasi) yang tidak mendukung juga harus diatasi.

\section{Perancangan Program}

Tabel 16. Strategi, Program dan Indikator Kinerja PBB Kota Cimahi.

\begin{tabular}{|c|c|c|c|}
\hline Kode & Uraian Strategi & Program & Indikator kinerja \\
\hline PCC & $\begin{array}{l}\text { Aging Schedule } \\
\text { Piutang }\end{array}$ & $\begin{array}{l}\text { Pengelolaan keuangan daerah } \\
\text { PBB secara Accrual Basic }\end{array}$ & $\begin{array}{l}\text { Persentase Penggolongan } \\
\text { Kualitas Piutang PBB }\end{array}$ \\
\hline VCC & Ekstensifikasi PBB & $\begin{array}{l}\text { Pembaharuan } \\
\text { SISMIOP PBB }\end{array}$ & $\begin{array}{l}\text { Persentase kenaikan Ketetapan } \\
\text { PBB Murni }\end{array}$ \\
\hline VIC & Intensifikasi PBB & Monitoring Aparatur PBB & $\begin{array}{l}\text { Pemberian reward dan } \\
\text { punishment aparatur } \mathrm{PBB}\end{array}$ \\
\hline VCE & $\begin{array}{l}\text { Pekan Panutan } \\
\text { PBB }\end{array}$ & Forum Group Discusion PBB & $\begin{array}{l}\text { Persentase kenaikan } \\
\text { pendapatan PBB }\end{array}$ \\
\hline PRE & $\begin{array}{l}\text { Klasifikasi Piutang } \\
\text { PBB }\end{array}$ & $\begin{array}{l}\text { sistem tata kelola Keuangan } \\
\text { Daerah dalam Piutang PBB }\end{array}$ & $\begin{array}{l}\text { Persentase pengolongan empat } \\
\text { klasifikasi kualitas piutang }\end{array}$ \\
\hline VRR & $\begin{array}{l}\text { Percepatan PBB } \\
\text { Lunas }\end{array}$ & $\begin{array}{lll}\text { Penagihan } & \text { Pembayara } & \text { PBB } \\
\text { Keliling } & & \\
\end{array}$ & $\begin{array}{l}\text { Pemberian Reward bagi Wajib } \\
\text { Pajak PBB }\end{array}$ \\
\hline RDR & $\begin{array}{l}\text { Peraturan (Fasum) } \\
\text { bebas PBB }\end{array}$ & $\begin{array}{l}\text { Meningkatkan ketersediaan } \\
\text { fasilitas sosial dan umum }\end{array}$ & $\begin{array}{l}\text { Persentase Fasilitas Umum } \\
\text { (Fasum) bebas PBB }\end{array}$ \\
\hline PRR & $\begin{array}{l}\text { Pengurangan } \\
\text { Piutang PBB }\end{array}$ & $\begin{array}{l}\text { PenagihanNet } \\
\text { ValuePiutang } \\
\text { progresif. }\end{array}$ & $\begin{array}{l}\text { Persentase pendapatan dari } \\
\text { potensi Piutang PBB }\end{array}$ \\
\hline RCD & $\begin{array}{l}\text { Peraturan Kawasan } \\
\text { Nasional }\end{array}$ & $\begin{array}{l}\text { PemberdayaanOtonomi } \\
\text { Kawasan Strategis Nasional }\end{array}$ & $\begin{array}{l}\text { Pendataan ulang potensi PBB } \\
\text { di Kawasan Strategis Nasional }\end{array}$ \\
\hline SID & $\begin{array}{l}\text { Organisasi } \\
\text { Pengelola PBB }\end{array}$ & $\begin{array}{l}\text { kepatuhan hukum kelembagaan } \\
\text { dan organisasi pemerintah }\end{array}$ & $\begin{array}{l}\text { Penambahan bidang PBB } \\
\text { dalam SKPD }\end{array}$ \\
\hline VID & $\begin{array}{l}\text { Efektifitas } \\
\text { Pengelolaan PBB }\end{array}$ & $\begin{array}{ll}\text { Optimalisasi } & \text { Derajat } \\
\text { Desentralisasi PBB } & \end{array}$ & $\begin{array}{l}\text { Derajat Desentralisasi PBB } \\
\text { diatas enam persen. }\end{array}$ \\
\hline RCA & $\begin{array}{l}\text { Peraturan PBB } \\
\text { Rusunawa }\end{array}$ & $\begin{array}{l}\text { Insentif PBB Obyek Pajak } \\
\text { Rumah Susun Warga (Rusunwa) }\end{array}$ & $\begin{array}{l}\text { Terbitnya Peraturan Walikota } \\
\text { perihal (Rusunawa) }\end{array}$ \\
\hline VIA & $\begin{array}{l}\text { Kontribusi PBB } \\
\text { terhadap APBD }\end{array}$ & $\begin{array}{l}\text { Peningkatan akuntabititas } \\
\text { kinerja PBB indikator Value For } \\
\text { Money }\end{array}$ & $\begin{array}{l}\text { Persentase perbandingan } \\
\text { Value For Money (periode) }\end{array}$ \\
\hline SCS & $\begin{array}{l}\text { Pemekaran } \\
\text { Kecamatan }\end{array}$ & Tata Kelola Kecamatan baru & $\begin{array}{l}\text { Jumlah kecamatan minimal } \\
\text { empat }\end{array}$ \\
\hline RIS & $\begin{array}{l}\text { Peraturan NJOP } \\
\text { PBB }\end{array}$ & $\begin{array}{ll}\text { Produktifitas } & \text { Penetapan Nilai } \\
\text { Jual Obyek } & \text { PajakBumi dan } \\
\text { Bangunan } & \end{array}$ & $\begin{array}{l}\text { Terbitnya Peraturan Walikota } \\
\text { pertahun. }\end{array}$ \\
\hline PDS & $\begin{array}{l}\text { Penghapusan } \\
\text { Piutang }\end{array}$ & $\begin{array}{l}\text { Penghapusanpiutang PBB yang } \\
\text { transparan dan akuntabel }\end{array}$ & $\begin{array}{l}\text { Persentase dihapusbukukan } \\
\text { Piutang PBB (hapus tagih) }\end{array}$ \\
\hline
\end{tabular}

KESIMPULAN DAN SARAN 


\section{Simpulan}

1. Sesuai dengan amanah paket undang-undang terkait PBB, Pemerintah Kota Cimahi masih kurang regulasinya sebagiai legal standing dan operasional.

2. Penyelesaian piutang sesuai standar akuntansi basis akrual, Pemerintah Kota Cimahi belummelakukan pemutakhiran dan validasi data, aging schedule, perhitungan penyisihan, dan $N R V$ (Net Realizable Value)dari pelimpahan piutang database pusat ke daerah maupun piutang murni pasca cut off desentralisasi fiskal.

3. Struktur Organisasi dan Tata Kerja (SOTK) dan Sumber Daya Manusia (SDM) aparatur Pemerintah Kota Cimahi belum berjalan dinamis dan responsif.

4. Pasca desentralisasi fiskal Pajak Bumi dan Bangunan Kota Cimahi melalui indikator-indikator Value For Money (VFM) belum berjalan secara optimal.

\section{Saran}

1. Melakukan Kajian Pembangunan Daerah (KPD) Kota Cimahi tata kelola pendapatan daerah dalam Kawasan Strategis Nasional sebagai solusi pembangunan daerah.

2. Menganalisis Upaya Fiskal PBB Pemkot Cimahi melengkapi indikator Value For Money (VFM)guna menyempurnakan Role Model Kajian Desentralisasi Fiskal PBB

3. Melaksanakan Kajian bersama stakeholder Rencana Pembangunan Jangka Menengah (RPJM) 2017 - 2022 Pemerintah Kota Cimahi

\section{DAFTAR PUSTAKA}

Astomo P.2014. Hukum Tata Negara Teori Dan Praktek. Yogyakarta (ID): Thafa Media

Ayse. 2015. Innovation for a New Tax Incentive:J. Patent Box Regime Turkey and the EU Application Procedia - Social and Behavioral Sciences 195 ( 2015 ) 544 - 553

Allison M, Kaye J. 2013. Perencanaan Strategis. Jakarta (ID): Pustaka Obor Indonesia

Awi S. 2004. Strategi Peningkatan Pendapatan Asli Daerah (PAD) Di Kabupaten Indragiri Hilir. [tesis]. Bogor. Institut Pertanian Bogor

Banapon AM. 2009. Strategi Peningkatan Pendapatan Asli Daerah Dalam Rangka Otonomi Daerah di Kabupaten Kepulauan Sula [tesis]. Bogor. Institut Pertanian Bogor

Daphne L. 2014. Management In Absurd Way. Jakarta (ID). Elex Media Komputindo

Elena. 2015 Palette effect of taxes on economic, social and emotional welfare of the citizens. J.Procedia-Social and Behavioral Sciences 166 (2015) 209 - 215

Gusri S. 2005. Efektifitas Pengelolaan Keuangan Daerah Kabupaten Bengkalis Di Era Otonomi[tesis]. Bogor. Institut Pertanian Bogor

Hamdani MA. 2007. Optimalisasi Peningkatan Pendapatan Pajak Restoran Di Kota Depok[tesis]. Bogor. Institut Pertanian Bogor

Hadin AF.2013.Eksistensi Badan Pengawasan Keuangan dan Pembangunan Di Era Otonom Daerah. Yogyakarta (ID): Genta Press

Helmi A. 2003. Hubungan Antara Belanja dan Penerimaan Daerah: Antara Belanja dan Penerimaan Daerah [tesis]. Bogor. Institut Pertanian Bogor

Islamy IM. 1984.Prinsip-Prinsip Perumusan Kebijaksanaan Negara.Jakarta (ID):Bumi Aksara

Kim WC, Mauborgne R. 2006. Blue Ocean Strategy: How to Create Uncontested Market Space and Make the Competition Irrelevant. Massachusetts (US):Harvard Business School Publishing Corporation

Lutfi A. 2006. Penyempurnaan Administrasi Pajak Daerah dan retribusi Daerah: Suatu upaya dalam optimalisasi penerimaan PAD. Jurnal Ilmu Administrasi dan Organisasi: Bisnis \& Birokrasi 14(1) 1 - 9

Makagansa. 2008.Tantangan Pemekaran Daerah.Yogyakarta (ID): FusPad

Miner JB, Steiner GA. 1997. Kebijakan dan Strategi Manajemen. Jakarta (ID): Erlangga

Mardiasmo. 2009. AkuntansiSektorPublik. Yogyakarta(ID): Andi Publisher

Makawimbang. 2014. Kerugian Keuangan Negara, Dalam Tindak PidanaKorupsi: Suatu Pendekatan Hukum Progresif.Yogayakarta (ID): Thafa Media

Muhadjir N. 2013.Metodologi Kajian Kebijakan Dan Evalusi Kebijakan. Yogyakarta (ID). Rake Sarasin 
Muhjad H, Nuswardani N. 2012. Penelitian Hukum Indonesia Kontemporer. Jakarta (ID): Genta Publising

Nasdian FT. 2014. Pengembangan Masyarakat. Jakarta (ID):Pustaka Obor Indonesia

Niazi, Tariq, Gyat N, Dermott MM. 2010.Strategy and Roadmap for Devolving the Property Tax, Fiskal Decentralization in Indonesia Series, Paper No. 1, Asian Development Bank, January 2010

Ofoegbu GN. 2014. New Public Management and Accrual Accounting Basis for Transparency and Accountability in the Nigerian Public Sector . IOSR Journal of Business and Management16(7): 104-113.

Pandiangan L. 2010. Hindari Kesalahan Pajak: Rakyat Senang Jika Anda Patuhi 37 Larangan Perpajakan. Jakarta (ID):Elex Media Komputindo Kompas Gramedia

Pemerintah Republik Indonesia. 2003. Undang-Undang Republik Indonesia Nomor 17 Tahun 2003 tentang Keuangan Negara. Jakarta (ID): Sekretariat Negara.

Pemerintah Republik Indonesia. 2004. Undang-Undang Republik Indonesia Nomor 1 Tahun 2004 tentang Perbendaharaan Negara. Jakarta (ID): Sekretariat Negara.

Pemerintah Republik Indonesia. 2004. Undang-Undang Republik Indonesia Nomor 15 Tahun 2004 tentang Pemeriksaan Pengelolaan dan Tanggung Jawab Keuangan Negara. Jakarta (ID): Sekretariat Negara.

Pemerintah Republik Indonesia. 2007. Undang-Undang Republik Indonesia Nomor 17 Tahun 2007 tentang Rencana Pembangunan Jangka Panjang Nasional Tahun 2005-2025. Jakarta (ID): Sekretariat Negara.

Pemerintah Republik Indonesia. 2007. Undang-Undang Republik Indonesia Nomor 26 Tahun 2007 tentang Penataan Ruang. Jakarta (ID): Sekretariat Negara.

Pemerintah Republik Indonesia. 2009. Undang-Undang Republik Indonesia Nomor 28 Tahun 2009 tentang Pajak Daerah dan Retribusi Daerah. Jakarta (ID): Sekretariat Negara.

Pemerintah Republik Indonesia. 2014. Undang-Undang Republik Indonesia Nomor 23 Tahun 2004 tentang Pemerintahan Daerah. Jakarta (ID): Sekretariat Negara.

Pemerintah Republik Indonesia. 2010. Peraturan Pemerintah Nomor 71 Tahun 2010 Tentang Standar Akuntansi Pemerintahan. Jakarta (ID): Sekretaris Negara

Rosidin U. 2010.Otonomi daerah Dan Desentralisasi, Bandung (ID):Pustaka Setia

Stefan. 2014. Property taxes and dynamic efficiency. J A correction, Economics Letters 123 (2014) 327-328

Sidharta BA. 2013. Ilmu Hukum Indonesia: Upaya Pengembangan Ilmu Hukum Sistematik Yang Responsif Terhadap Perubahan Masyarakat. Yogyakarta(ID): Genta Publising

Sinambela L, Bima D, Ghazali R, Muksin A, Rochadi S, Setiabudi D, Syaifudin. 2006. Reformasi Pelayanan Publik: Teori, Kebijakan dan Implementasi. Jakarta (ID):Bumi Aksara

Sembiring W. 2009. Strategi Pengembangan Potensi Sumber-Sumber Pendapatan asli Daerah Di Kabupaten Lampung Barat. [tesis]. Bogor. Institut Pertanian Bogor

Wuisman JJJM. 2013. Teori dan Praktek Memperoleh kembali kenyataan supaya memperoleh masa depan. Jakarta (ID): Pustaka Obor Indonesia

Zainuddin C. 2009. Strategi Pemanfaatan APBD Kabupaten Lampung Barat Serta Implikasinya Terhadap Pembangunan Daerah [tesis]. Bogor. Institut Pertanian Bogor 